\title{
Integrative literature review on COVID-19 racial ethnic disparities among black pregnant and postpartum women
}

\author{
Revisão integrativa da literatura sobre as disparidades étnicas raciais da COVID-19 entre gestantes e \\ puérperas pretas
}

\author{
Gabrielle Silva Cavalcante ${ }^{1}$, Maria Cristina Souza Santos ${ }^{1}$, Michele Monteiro de Andrade ${ }^{1}$, Rafaela \\ Bezerra de Melo ${ }^{1}$, Tatiane Siqueira de Oliveira ${ }^{2}$, Gustavo Gonçalves dos Santos ${ }^{2 *}$
}

\begin{abstract}
${ }^{1}$ Undergraduate Nursing student, Nursing School of the University of Santo Amaro, São Paulo, São Paulo, Brasil. ${ }^{2}$ Teacher of the Undergraduate Course in Nursing, School of Nursing at the University of Santo Amaro, São Paulo, São Paulo, Brasil. *Autor para correspondência. E-mail: ggsantos@prof.unisa.br
\end{abstract}

\begin{abstract}
Introduction: Black pregnant and postpartum women have a risk of death from COVID-19 almost twice as high as that of white women. Brazilian studies detail the impact of health service failures in this tragedy where $15 \%$ of pregnant or postpartum women who died from COVID-19 by July 2020 received no ventilatory assistance, $28 \%$ had no access to ICU, $36 \%$ were neither intubated nor received mechanical ventilation. Review: Integrative Literature Review (ILR), we adopted the following inclusion criteria: articles published from March 2020 onwards, articles available electronically and free of charge in databases/portals. Exclusion criteria were: articles that did not correspond to the time frame of 2020/2021, that were not in English and Portuguese, texts not available in full, duplicate articles in the database and review articles. The literature data collection was performed from May to July 2021, in the Web Of Science database/portal of Clarivate Analytics, Science Direct (SciVerse) of Elsevier Scientific Publications, National Library of Medicine (PUBMED) and Medical Literature Analysis and Retrieval System Online (MEDLINE). The following Health Sciences Descriptors (DeCS) were used: "COVID-19" OR "SARS-COV" AND "Black women" OR "Women black" AND" Pregnant" OR "Pregnancy" AND "Racism" OR "Racism". Discussion: For selection of articles, the search in the Web Of Science database began, resulting in 02 articles, of which 02 were selected for full reading and, after a critical and thorough reading, 01 article was included in the review. In Science Direct resulted in 02 articles, of which 02 were selected for full reading and, after a critical and thorough reading, 01 article was included in the review. In PUBMED, 26 articles resulted, 10 were selected for full reading and, after a critical and thorough reading, 6 articles were included in the review. Finally, MEDLINE resulted in 18 articles, of which 5 were selected for full reading and, after a critical and thorough reading, 3 articles were included in the review. Final considerations: The study included observational studies, with small samples and diverse ethnic groups, not allowing effective conclusions. They highlight Brazilian studies that used secondary and population-based databases, found black race/color as a risk factor independently associated with the severity of COVID-19.
\end{abstract}

Keywords: COVID-19, pregnancy, pregnant woman, racism, ethnic groups, maternal death.

Resumo: Introdução: As mulheres pretas grávidas e puérperas têm um risco de morte da COVID-19 quase duas vezes maior do que o das mulheres brancas. Estudos brasileiros detalham o impacto das falhas dos serviços de saúde nesta tragédia em que $15 \%$ das mulheres grávidas ou pós-parto que morreram da COVID19 até Julho de 2020 não receberam assistência ventilatória, 28\% não tiveram acesso à UTI, 36\% não foram entubadas nem receberam ventilação mecânica. Revisão: Revisão Integrativa da Literatura (RIL), adotando os seguintes critérios de inclusão: artigos publicados a partir de Março de 2020, artigos disponíveis electronicamente e gratuitamente em bases de dados/portais. Os critérios de exclusão foram: artigos que não correspondiam recorte temporal de 2020/2021, que não estavam em inglês e português, textos não disponíveis na íntegra, artigos duplicados na base de dados e artigos de revisão. A coleta de dados foi realizada de Maio a Julho de 2021, na base de dados/portal Web Of Science, Science Direct (SciVerse) de Elsevier Scientific Publications, National Library of Medicine (PUBMED) e Medical Literature Analysis and Retrieval System Online (MEDLINE). Foram utilizados os seguintes Descritores de Ciências da Saúde (DeCS): "COVID-19" OR "SARS-COV" AND "Mulheres Negras" OR "Mulheres Negras" AND "Grávidas" OR "Gravidez" AND "Racismo" OR "Racismo". Discussão: Para selecção de artigos, iniciou-se a pesquisa na base de dados Web Of Science, resultando em 02 artigos, dos quais 02 foram seleccionados para leitura completa e, após uma leitura crítica e completa, 01 artigo foi incluído na revisão. Em Science Direct foram seleccionados 02 artigos, dos quais 02 foram seleccionados para uma leitura completa e, após uma leitura crítica e exaustiva, 01 artigo foi incluído na revisão. No PUBMED, 26 artigos resultaram, 10 foram 
seleccionados para uma leitura completa e, após uma leitura crítica e exaustiva, 6 artigos foram incluídos na revisão. Finalmente, MEDLINE resultou em 18 artigos, dos quais 5 foram seleccionados para uma leitura completa e, após uma leitura crítica e exaustiva, 3 artigos foram incluídos na revisão. Considerações finais: O estudo incluiu estudos observacionais, com pequenas amostras e grupos étnicos diversos, não permitindo conclusões eficazes. Destacam os estudos brasileiros que utilizaram bases de dados secundárias e baseadas na população, encontraram a raça/cor preta como fator de risco independentemente associado à severidade da COVID-19.

Palavras-chave: COVID-19, gravidez, mulher grávida, racismo, grupos étnicos, morte materna.

\section{Introduction}

In December 2019 individuals began to develop severe respiratory illness of unknown cause in Wuhan, China. A beta coronavirus called Severe Acute Respiratory Syndrome Coronavirus 2 (SARS-COV-2) - Severe Acute Respiratory Syndrome 2, popularly known as Coronavirus Disease 2019 (COVID-19), was discovered to cause potentially severe respiratory tract infection with high transmissibility (Fiocruz, 2020).

On February 26, 2020 the first case of COVID-19 was confirmed in Brazil subsequently occurring the number of infected in the country which generated despair in the population. On March 11, 2020, the director general of the World Health Organization (WHO), declared a pandemic of the new coronavirus and on this, the same day the Federal District began measures of physical and social isolation (Malta et al., 2020).

The Ministry of Health (MOH) of Brazil considered risk groups, such as adults over 60 years, children under 5 years, indigenous population, individuals with pneumopathies, tuberculosis, cardiovasculopathies, nephropathies, liver diseases, hematological diseases, metabolic disorders, neurological disorders, immunosuppression and neoplasms (Brasil, 2020a).

About the evolution of the pandemic by COVID-19, it became important the definition of vulnerability groups, in these, included pregnant and postpartum women (Brasil, 2020b), because it recognizes that pregnancy is the period of several physiological changes, and pregnant women, during infections caused by other coronaviruses, such as SARS-CoV and Middle East Respiratory Syndrome Coronavirus (MERS-CoV), presented complications such as: fever, dyspnea and need for Intensive Care Unit (ICU) (Wong et al., 2003; Alfaraj et al., 2019) thus justifying the inclusion in the vulnerability group for SARS-CoV-2.In most cases the symptoms presented are mild, such as fever and dry cough, however, in women in the second half of pregnancy, other symptoms may appear with intensity, such as: fatigue, dyspnea, diarrhea, being also possible evolution to severe complications, such as Severe Acute Respiratory Syndrome (SARS) (Zaigham \& Andersson, 2020).

Considering that the literature has shown unfavorable maternal and neonatal outcomes in the presence of moderate and severe COVID-19 (Brasil, 2020b). According to the Pan American Health Organization (PAHO), the lethality rate of pregnant and postpartum women by COVID-19 in Brazil are nine times higher than the average of the Americas (PAHO/WHO, 2020).

Black pregnant and postpartum women have a risk of death from COVID-19 almost twice as high as that of white women. Brazilian studies detail the impact of health service failures in this tragedy where $15 \%$ of pregnant or postpartum women who died from COVID - 19 by July 2020 received no ventilatory assistance, $28 \%$ had no access to ICU, $36 \%$ were neither intubated nor received mechanical ventilation (Takemoto, et al., 2020a).

A group of Brazilian researchers have published articles warning about the risk of maternal death by COVID-19. In one of the studies, data from the Influenza Epidemiological Surveillance Information System (SIVEP Gripe), available from the Brazilian Ministry of Health, was analyzed, 7\% mortality rate) it is evident that the death rate in relation to the rest of the world was exceeded, it was also observed serious errors in assistance, $15 \%$ of women had not received ventilatory support, $28 \%$ did not receive access to ICU bed and $36 \%$ did not receive invasive or non-invasive mechanical ventilation (Takemoto, et al., 2020a). Another study of this same group carried out in 2020 points out that 160 international deaths were registered and of these, eight out of every 10 occurred in Brazil (Nakamura-Pereira et al., 2020).

A study published in May 2021, through a literature review, the authors report that the data discussed in the study focused on the search for evidence on the evolution of COVID-19 according to skin color in pregnant/puerperal women. The authors describe that it was not possible to establish a clear relationship between skin color and negative outcomes among black pregnant women/puerperae, but reinforces that two Brazilian studies found black race/color as a risk factor independently associated with the severity of COVID19 (Santos et al., 2021). 
Given the failures in the health systems of low- and middle-income countries, it appears that maternal deaths are more frequent in these countries when associated with the determinants of the health-disease process (Furlan et al., 2020). Considering the risk factors of COVID-19 associated with pregnant and postpartum women who self-declare as black and brown, this study is justified, since shared data reinforce maternal mortality in black women due to COVID-19.

\section{Revision}

This is an Integrative Literature Review (ILR), a method that enables the synthesis of previously published studies, allowing the construction of new knowledge, based on the results presented by previous research (Mendes \& Silveira; Galvão, 2008; Benefield, 2003; Polit \& Beck, 2006). The ILR is conducted through scientific and literary survey, for the process of its construction we followed six phases: 1 - development of the guiding question, 2 - literature search, 3 - data collection, 4 - critical analysis of the studies included, 5 discussion of results and 6 - presentation of the review (SOUZA, 2010).

For the development of the ILR it was used the PICO strategy, Patient, Intervention, Comparison and Outcomes (outcome), in which "P" - black and brown pregnant women with COVID-19, "I" - Hospitalization, "C" - black pregnant women compared to white and "O" - death by COVID-19, thus questioning: What factors lead black pregnant women to have worse evolution by COVID-19 when compared to white pregnant women?

We adopted the following inclusion criteria: articles published from March 2020 onwards, articles available electronically and free of charge in databases/portals. Exclusion criteria were: articles that did not correspond to the time frame of 2020/2021, that were not in English and Portuguese, texts not available in full, duplicate articles in the database and review articles.

The literature data collection was performed from May to July 2021, in the Web Of Science database/portal of Clarivate Analytics, Science Direct (SciVerse) of Elsevier Scientific Publications, National Library of Medicine (PUBMED) and Medical Literature Analysis and Retrieval System Online (MEDLINE). The following Health Sciences Descriptors (DeCS) were used: "COVID-19" OR "SARS-COV" AND "Black women" OR "Women black" AND" Pregnant" OR "Pregnancy" AND "Racism" OR "Racism".

\section{Discussion}

For selection of articles, the search in the Web Of Science database began, resulting in 02 articles, of which 02 were selected for full reading and, after a critical and thorough reading, 01 article was included in the review. In Science Direct resulted in 02 articles, of which 02 were selected for full reading and, after a critical and thorough reading, 01 article was included in the review. In PUBMED, 26 articles resulted, 10 were selected for full reading and, after a critical and thorough reading, 6 articles were included in the review. Finally, MEDLINE resulted in 18 articles, of which 5 were selected for full reading and, after a critical and thorough reading, 3 articles were included in the review.

A descriptive study conducted in the US, reports that the majority of pregnant women hospitalized for COVID-19 were black and had some type of comorbidities (Vousden et al., 2021). Another study conducted in the US between March 1, 2020 and June 30, 2020, involving pregnant women from racial and ethnic groups found that the SARS-CoV-2 infection rate was $70 \%$ higher in pregnant patients from this group, racial and ethnic health disparities, socioeconomic inequality, structural racism, education, quality housing were the factors causing these discrepancies according to the authors (Jani et al., 2021).

In contrast a research shows unsatisfactory results, in which SARS-COV 2 infected pregnant black women are more likely to develop depression, anxiety, more likely to have their financial life negatively impacted after confirmation of the disease (Gur et al., 2020). In an observational cohort, several risk factors for SARSCoV-2 infection were identified, including identification with a racial minority subgroup, where positive test results were more frequent among young pregnant women and were more likely to be publicly insured, black or African American or Latina, unmarried, obese, have preexisting lung disease, and have live children (Sakowicz et al., 2020).

In Brazil, black pregnant women were hospitalized in worse conditions, with a higher prevalence of dyspnea and lower oxygen saturation, and had higher rates of ICU admission, mechanical ventilation, and death. The study also showed that maternal mortality in black women was almost twice as high as that observed in white women (Souza Santos et al., 2020). Other Brazilian studies show that black pregnant women 
are at higher risk for developing severe features of COVID-19, with chances of adverse outcomes, hospital admissions, impeded access to intensive care, and medical conditions in harmful situations, resulting in increased risk of death (Menezes et al., 2020).

The difficulty in access to health care, disparities in the pandemic containment measure in order to decrease the curve and avoid mass contagion, and the high prevalence of coexisting risk factors for the severe disease of COVID-19, are factors that may cause discrepancy when compared to worldwide reports regarding maternal outcomes. In Brazil, obstetric care is affected by chronic problems such as low quality prenatal care, insufficient resources to manage emergency and critical care, racial disparities in access to maternity services, obstetric violence, and the pandemic represent additional barriers to access to health care (Takemoto, et al., 2020a; Takemoto et al., 2020b; Amorim et al., 2020).

The estimated incidence of hospital admission with confirmed SARS-CoV-2 infection in pregnancy was 4.9 per 1000 maternity hospitals, where 233 (56\%) pregnant women admitted with SARS-CoV-2 infection were from black or other ethnic minority groups, 281 (69\%) were overweight or obese, 175 (41\%) were 35 years or older, and 145 (34\%) had pre-existing comorbidities. 266 (62\%) (Knight et al., 2020).

It was noted that for every 1,000 pregnant women hospitalized 4.9 were with SARS-CoV-2 infection. In a sample of 427 pregnant women hospitalized with SARS-CoV-2, 233 (56\%) were black or from other minority ethnic groups, of these 41 (10\%) required ventilatory support. The majority had mild manifestations such as cough, fever, and shortness of breath and the minority developed severe disease $41(10 \%)$ required intensive care, 5 (42\%) of the women confirmed with SARS-CoV-2 died and 3 more died from Covid-19 complications. It can be noted that more than half of the pregnant women admitted with SARS-CoV-2 infection were black or other minority ethnic groups (Lokken et al., 2020).

\section{Final Considerations}

We conclude that the situation of COVID-19 is aggravated by the fact that conservative and excluding policies are still present in the current Brazilian reality, where women are the main victims of neglect and negligence. The black population, therefore, is the biggest victim of both the physical impacts caused by COVID-19 and the economic factors. The study included observational studies, with small samples and diverse ethnic groups, not allowing effective conclusions. They highlight Brazilian studies that used secondary and population-based databases, found black race/color as a risk factor independently associated with the severity of COVID-19.

\section{References}

Alfaraj, S. H., Al-Tawfiq, J. A., \& Memish, Z. A. 2019. Middle East Respiratory Syndrome Coronavirus (MERS$\mathrm{CoV}$ ) infection during pregnancy: Report of two cases \& review of the literature. Journal of Microbiology, Immunology and Infection, 52(3), 501-3.

Amorim, M. M. R., Soligo, T. M. L., \& Fonseca, E. B. 2020. Maternal deaths with coronavirus disease 2019: a different outcome from low- to middle-resource countries? American Journal of Obstetrics \& Gynecology, 223(2), 298-299.

Benefield, L. E. 2003. Implementing evidence-based practice in home care. Home Healthcare Now, 21(12), 804-809

Brasil, Ministério da Saúde. 2020a. Recomendação n 020 de 07 de Abril de 2020 - Recomenda a observância do Parecer Técnico $n^{\circ}$ 128/2020, que dispõe sobre as orientações ao trabalho/atuação dos trabalhadores e trabalhadoras, no âmbito dos serviços de saúde, durante a Emergência em Saúde Pública de Importância Nacional em decorrência Doença por Coronavírus - COVID-19. 2020a. isponível em: http://conselho.saude.gov.br/recomendacoes-cns/1103-recomendac-a-o-no-020-de-07-de-abril-de2020. Acesso em: 08 jun 2021.

Brasil, Ministério da Saúde. 2020b. Secretaria de Atenção Primária à Saúde. Departamento de Ações Programáticas e Estratégica. Nota Informativa no 13/2020 - SE/GAB/SE/MS - Manual de Recomendações para a Assistência à Gestante e Puérpera frente à Pandemia de Covid-19 [recurso eletrônico] / Ministério da Saúde, Secretaria de Atenção Primária à Saúde. - Brasília: Ministério da Saúde. Disponível em: http://189.28.128.100/dab/docs/portaldab/documentos/corona/manual_recomendacoes_gestantes_covid1 9.pdf. Acesso em: 08 jun 2021. 
Fundação Oswaldo Cruz [FIOCRUZ]. 2020. Por que a doença causada pelo novo coronavírus recebeu o nome de Covid-19? Disponível em: https://portal.fiocruz.br/pergunta/por-que-doenca-causada-pelo-novocoronavirus-recebeu-o-nome-de-covid-

19\#: :text=COVID\%20significa\%20COrona\%20VIrus\%20Disease,chin\%C3\%AAs\%20no\%20final\%20de\%2 Odezembro. Acesso em: 08 jun 2021.

Furlan, M. C. R., Jurado, S. R., Uliana, C. H., da Silva, M. E. P., Nagata, L. A., \& Maia, A. C. F. 2020. Gravidez e infecção por Coronavírus: desfechos maternos, fetais e neonatais-Revisão sistemática. Revista Cuidarte, 11(2), 1-15.

Gur, R. E., White, L. K., Waller, R., Barzilay, R., Moore, T. M., Kornfield, S., ... \& Elovitz, M. A. 2020. The Disproportionate Burden of the COVID-19 Pandemic Among Pregnant Black Women. Psychiatry Research, 293, 113475.

Jani, S., Jacques, S. M., Qureshi, F., Natarajan, G., Bajaj, S., Velumula, P., ... \& Bajaj, M. (2021). Clinical Characteristics of Mother-Infant Dyad and Placental Pathology in COVID-19 Cases in Predominantly African American Population. American Journal of Perinatology Reports, 11(01), e15-e20.

Knight, M., Bunch, K., Vousden, N., Morris, E., Simpson, N., Gale, C., ... \& Kurinczuk, J. J. 2020. Characteristics and outcomes of pregnant women admitted to hospital with confirmed SARS-CoV-2 infection in UK: national population based cohort study. BMJ, 369.

Lokken, E. M., Taylor, G. G., Huebner, E. M., Vanderhoeven, J., Hendrickson, S., Coler, B., ... \& COVID, W. 2021. Higher severe acute respiratory syndrome coronavirus 2 infection rate in pregnant patients. American journal of obstetrics and gynecology, 225(1), 75.e1-75.e16

Malta, D. C., Szwarcwald, C. L., Barros, M. B. D. A., Gomes, C. S., Machado, Í. E., Souza, P. R. B. D., ... \& Gracie, R. 2020. A pandemia da COVID-19 e as mudanças no estilo de vida dos brasileiros adultos: um estudo transversal, 2020. Epidemiologia e Serviços de Saúde, 29.

Mendes, K. D. S., Silveira, R. C. C. P., \& Galvão, C. M. 2008. Revisão integrativa: método de pesquisa para a incorporação de evidências na saúde e na enfermagem. Texto \& Contexto - Enfermagem, 17(4), 758-764.

Menezes, M. O., Takemoto, M. L., Nakamura-Pereira, M., Katz, L., Amorim, M. M., Salgado, H. O., ... \& Brazilian Group of Studies for COVID-19, Pregnancy. (2020). Risk factors for adverse outcomes among pregnant and postpartum women with acute respiratory distress syndrome due to COVID-19 in Brazil. International Journal of Gynecology \& Obstetrics, 151(3), 415-423.

Nakamura-Pereira, M., Amorim, M. M. R., Pacagnella, R. D. C., Takemoto, M. L. S., Penso, F. C. C., RezendeFilho, J. D., \& Leal, M. D. C. (2020). COVID-19 and maternal death in Brazil: an invisible tragedy. Revista Brasileira de Ginecologia e Obstetrícia, 42(8), 445-447.

Organização Pan-Americana da Saúde/Organização Mundial de Saúde. 2020. Actualización Epidemiológica: Enfermedad por coronavirus (COVID-19) - 18 de septiembre de 2020. Disponível em: https://www.paho.org/es/documentos/actualizacion-epidemiologica-enfermedad-por-coronaviruscovid-19-18-septiembre-2020. Acesso em: 08 jun 2021.

Polit, D. E. \& Beck, C. T. 2006. Essentials of Nursing Research (6th Edition). Philadelphia: Lippincott Williams \& Wilkins.

Santos, G. G., Andrade, L. H., Magaton, A. P. F. S., \& Parada, C. M. G. Lima. 2021. Effects of COVID-19 among black and mulatto pregnant women: Integrative literature review. Research, Society and Development, 10(6), e6710615531.

Souza Santos, D., de Oliveira Menezes, M., Andreucci, C. B., Nakamura-Pereira, M., Knobel, R., Katz, L., ... \& Takemoto, M. L. 2020. Disproportionate impact of COVID-19 among pregnant and postpartum Black Women in Brazil through structural racism lens. Clinical Infectious Diseases: An Official Publication of the Infectious Diseases Society of America. Clinical Infectious Diseases, 72(11), 2068-2069.

Sakowicz, A., Ayala, A. E., Ukeje, C. C., Witting, C. S., Grobman, W. A., \& Miller, E. S. 2020. Risk factors for severe acute respiratory syndrome coronavirus 2 infection in pregnant women. American Journal of Obstetrics \& Gynecology MFM, 2(4), 100198.

Souza, M. T., Sila, M. D., \& Carvalho, R. 2010. Revisão integrativa: o que é e como fazer? Einstein, 8(1), 102-106.

Takemoto, M. L., Menezes, M. D. O., Andreucci, C. B., Nakamura-Pereira, M., Amorim, M. M., Katz, L., \& Knobel, R. 2020. The tragedy of COVID-19 in Brazil: 124 maternal deaths and counting. International Journal of Gynecology \& Obstetrics, 151(1), 154-156. 
Takemoto, M. L., Menezes, M. O., Andreucci, C. B., Knobel, R., Sousa, L. A., Katz, L., ... \& Amorim, M. M. (2020). Maternal mortality and COVID-19. The Journal of Maternal-Fetal \& Neonatal Medicine, 1-7.

Vousden, N., Bunch, K., Morris, E., Simpson, N., Gale, C., O’Brien, P., ... \& Knight, M. 2021. The incidence, characteristics and outcomes of pregnant women hospitalized with symptomatic and asymptomatic SARSCoV-2 infection in the UK from March to September 2020: a national cohort study using the UK Obstetric Surveillance System (UKOSS). PloS one, 16(5), e0251123.

Wong, S. F., Chow, K. M., Leung, T. N., Ng, W. F., Ng, T. K., Shek, C. C., ... \& Tan, P. Y. (2004). Pregnancy and perinatal outcomes of women with severe acute respiratory syndrome. American journal of obstetrics and gynecology, 191(1), 292-297.

Zaigham, M., \& Andersson, O. 2020. Maternal and Perinatal Outcomes with Covid-19: a systematic review of 108 pregnancies. Acta Obstetricia et GynecologicaScandinavica, 99(7), 823-829.

\section{Minicurrículo}

Gabrielle Silva Cavalcante. Undergraduate Nursing student. Nursing School of the University of Santo Amaro - UNISA. São Paulo - SP, Brazil.

Maria Cristina Souza Santos. Undergraduate Nursing student. Nursing School of the University of Santo Amaro - UNISA. São Paulo - SP, Brazil.

Michele Monteiro de Andrade. Undergraduate Nursing student. Nursing School of the University of Santo Amaro - UNISA. São Paulo - SP, Brazil.

Rafaela Bezerra de Melo. Undergraduate Nursing student. Nursing School of the University of Santo Amaro - UNISA. São Paulo - SP, Brazil.

Tatiane Siqueira de Oliveira. Undergraduate Nursing student. Nursing School of the University of Santo Amaro - UNISA. São Paulo - SP, Brazil.

Gustavo Gonçalves dos Santos. Graduated in Nursing from the School of Health Sciences of the Anhembi Morumbi University (EE-UAM). Specialist in Obstetric Nursing from the Israelite College of Health Sciences of the Albert Einstein Hospital - Israelite Institute of Teaching and Research (FHIAE). Master's degree from the Postgraduate Program in Collective Health of the Faculty of Medicine of Botucatu, Paulista State University Júlio de Mesquita Filho (FMB-UNESP). Currently, Adjunct Professor of the Nursing Department of the Undergraduate Nursing course and of the Lato Sensu Postgraduate Course in Obstetric Nursing of the University of Santo Amaro (UNISA).

Como citar: Cavalcante, G.S., Santos, M.C.S., Andrade, M.M., Melo, R.B., Oliveira, T.S., \& Santos, G.G. 2021. Integrative Literature Review on COVID-19 racial ethnic disparities among black pregnant and postpartum women. Pubsaúde, 8, a248. DOI: https://dx.doi.org/10.31533/pubsaude8.a248

Recebido: 02 set. 2021.

Revisado e aceito: 26 set. 2021.

Conflito de interesse: os autores declaram, em relação aos produtos e companhias descritos nesse artigo, não ter interesses associativos, comerciais, de propriedade ou financeiros que representem conflito de interesse.

Licenciamento: Este artigo é publicado na modalidade Acesso Aberto sob a licença Creative Commons Atribuição 4.0 (CC-BY 4.0). 